\title{
Effect of Heat Treatments on Polycyclic Aromatic Hydrocarbons Formation in Meat
}

\author{
Elsaid A. Eldaly ${ }^{1}$, Abd-Elsalam E. Hafez ${ }^{1}$, Wageh S. Darwish ${ }^{1}$, Rania M. Abd El-Hamid ${ }^{2}$, Doaa \\ F. Elmalt ${ }^{1 *}$ \\ ${ }^{1}$ Food Control Department, Faculty of Veterinary Medicine, Zagazig University, 44511, Egypt \\ ${ }^{2}$ Pesticide Residues and Environmental Pollution Department, Central Agricultural Pesticide \\ Laboratory, Agricultural Research Center. Dokki, Giza, Egypt
}

\begin{abstract}
A total of 80 samples of both beef and mutton (40, each), which were either raw or cooked by different cooking methods such as pan-frying, charcoal-grilling and charcoal-grilling with aluminum foils covers ( $\mathrm{n}=10$ for each of beef and mutton) besides 10 samples from raw meat of each type. The samples were collected from different restaurants at Zagazig City, Sharkia Governorate, Egypt. The samples were prepared for detection of 16 polycyclic aromatic hydrocarbons (PAHs) (naphthalene, acenaphthylene, acenaphthene, fluorene, phenanthrene, anthracene, fluoranthene, pyrene, benzo [a] anthracene, chrysene, benzo [b] fluoranthrene, benzo [k] fluoranthene, benzo [a] pyrene, Indeno [1,2,3c-d] pyrene, Dibenzo [a,h] anthracene and Benzo [g,h,i] perylene). The recorded results showed that the total PAHs for raw, fried, charcoal grilled and foil grilled beef samples were $0.247,1.152,6.833$ and $1.265 \mu \mathrm{g} / \mathrm{kg}$ respectively. Meanwhile, PAHs residual concentrations in mutton samples were 1.09, 4.606, 26.819 and 6.279 $\mu \mathrm{g} / \mathrm{kg}$ in raw, pan-fried, charcoal-grilled and foil-grilled mutton samples respectively. We found also when meat wrapped in aluminum foil during grilling, it leads to a decrease in the total PAHs in the meat samples.
\end{abstract}

Keywords: PAHs, Pan-frying, Charcoal-grilling, Foil-grilled, Aluminum foil

\section{Introduction}

Polycyclic aromatic hydrocarbons are wide spread as environmental pollutants, which can be generated during the preparation of food [1]. PAHs are originated from many sources of environment (natural and anthropogenic), industry of food processing (such as; heating, drying, and smoking processes), materials of package and some cooking practices (such as; grilling, roasting, and frying processes) [2]. Food is the main source of exposure to PAHs for people who do not smoke, diet may cause more than $90 \%$ of total PAHs exposure of general population in different countries [3]. For mean consumers across the European countries, dietary exposure for the sum of eight carcinogenic and genotoxic PAHs (PAH8) (chrysene, benzo [a] pyrene, benzo [b] fluoranthene, benzo [k] fluoranthene, dibenzo [a,h] anthracene, benzo [g,h,i] perylene, indeno [1,2,3-c,d] pyrene and fluorene) was estimated at $1.73 \mathrm{mg} / \mathrm{kg}$ [2]. Despite the high level of PAHs is not observed in raw food as usual, the grilled food has been reported to contain PAHs at levels of 0 to $130 \mathrm{mg} / \mathrm{kg}$ $[4,5]$. The difference in PAHs levels in food could be attributed to the type and fat content, process of cooking (fried, grilled, roasted, boiled and smoked), temperature and cooking duration as well as fuel type used (electrical, gas, wood, and charcoal) [5].

Benzo [a] pyrene $(\mathrm{BaP})$ is probably the most studied PAH. The International Agency for Research on Cancer (IARC) described BaP as probable human carcinogen in 1987 [6]. Thus, the BaP determination has been widely used in the analysis of the environment as an indicator for the PAH content [7]. Meat meals that are cooked by charcoal grilling and panfrying are common at both home and restaurants in Egypt, also in other Arabian countries. Therefore, this study was performed to determine the effect of different cooking methods on the formation of PAHs in meat. 


\section{Material and Methods}

\section{Samples}

A total of 80 samples of both beef and mutton (40, each), which were either raw or cooked by different cooking methods (panfrying, charcoal-grilling and charcoal-grilling with aluminum foils covers, $n=10$ for each beef and mutton). Samples were collected from different restaurants at Zagazig City, Sharkia Governorate, Egypt. The samples were prepared for the detection of 16 polycyclic aromatic hydrocarbons (PAHs) (naphthalene, acenaphthylene, acenaphthene, fluorene, phenanthrene, anthracene, fluoranthene, pyrene, benzo [a] anthracene, chrysene, benzo [b] fluoranthrene, benzo [k] fluoranthene, benzo [a] pyrene, Indeno [1,2,3c-d] pyrene, Dibenzo [a,h] anthracene and Benzo [g,h,i] perylene).

The beef and mutton samples were fried in small amounts of margarine. For charcoalgrilling, beef and mutton samples were grilled over a grill fueled by charcoal at different restaurants and shops till the color became yellowish brown (well done). In addition, for charcoal grilling with aluminum foils, beef and mutton samples were wrapped by aluminum foils then grilled on a grill till the color became yellowish brown (well done).

\section{Extraction and preparation of samples}

Samples were transferred in a separate labeled aluminum foil to the Pesticide Residue Department, Central Pesticide Laboratory, Agriculture Research Center, Giza, where the extraction procedures, clean up and estimation of PAH levels by gas chromatography were conducted. Analysis of the PAHs residues was done according to Villeneuve et al. [8]. Twenty grams from each examined sample were grinded in a mortar with anhydrous sodium sulfate $(2 \mathrm{~g})$. The mixture was then squeezed with $60 \mathrm{~mL}$ of hexane-acetone (1-1) (v/v) mixture, filtered and the tissue was extracted twice more. Organic solvent fractions were united and filtered through filter paper with $1 \mathrm{~g}$ anhydrous sodium sulfate. The extract was then evaporated to about $2 \mathrm{~mL}$. The extract was transferred to a round-bottom flask and $100 \mathrm{~mL}$ of $10 \%$ aqueous methanolic potassium hydroxide were added. The mixture was refluxed for $3 \mathrm{~h}$ in order to saponify the lipids. Finally, the content found in roundbottom flask was transferred to a separately funnel and cleansed with $150 \mathrm{~mL}$ of methanolwater $(4: 1)(\mathrm{vlv})$ mixture, then extracted with hexane $(80 \mathrm{~mL})$ to get back the non-saponified lipids.

\section{Clean up of samples}

Clean up was achieved with a silica/alumina column. Aromatic hydrocarbons were eluted with $30 \mathrm{ml}$ of a mixture of hexane and dichloromethane (90:10) (v/v). The volume of the eluted fraction was reduced to $1 \mathrm{~mL}$ and analyzed by a gas liquid chromatography equipped with a flame ionization detector GC/FID.

\section{Preparation of blank solution}

The same volume of solvents and anhydrous sodium sulfate, that were used in the PAHs extraction of the examined samples were exposed to the same routine for the detection of any possible traces of the studied PAHs in the solvents or distilled water.

\section{Gas chromatographic analysis}

The procedure was carried out according to Moret and Conte [9]. The polycyclic aromatic hydrocarbon fraction was injected into a gas liquid chromatography equipped with a flame ionization detector GC/FID. The gas chromatograph used was Hewlett Packard GC Model 6890 equipped with a flame ionization detector (GC/FID). GC analysis was conducted on HP-608 (Agilent, Folsom, CA) fused silica capillary column (30-meter length $\mathrm{x} 0.53$ millimeter internal diameter x 0.5 micrometer film thickness).

\section{Gas chromatography operating conditions}

Injector and detector temperatures were maintained at $280^{\circ} \mathrm{C}$ and $300^{\circ} \mathrm{C}$, respectively. Initial oven temperature, $100^{\circ} \mathrm{C}$ for 2 min hold to $280^{\circ} \mathrm{C}$ at the rate of $6^{\circ} \mathrm{C} / \mathrm{min}$ and was maintained at $280^{\circ} \mathrm{C}$ for $15 \mathrm{~min}$.

\section{Determination of the recovery percentage}

The recoveries were done by adding the standard of PAHs mixture at 3 concentrations (1, 5 and 10 micrograms). The average percentages of recovery of PAHs for the examined samples at 3 levels were determined and estimated for all the tested PAHs in each sample (Figure 1). 


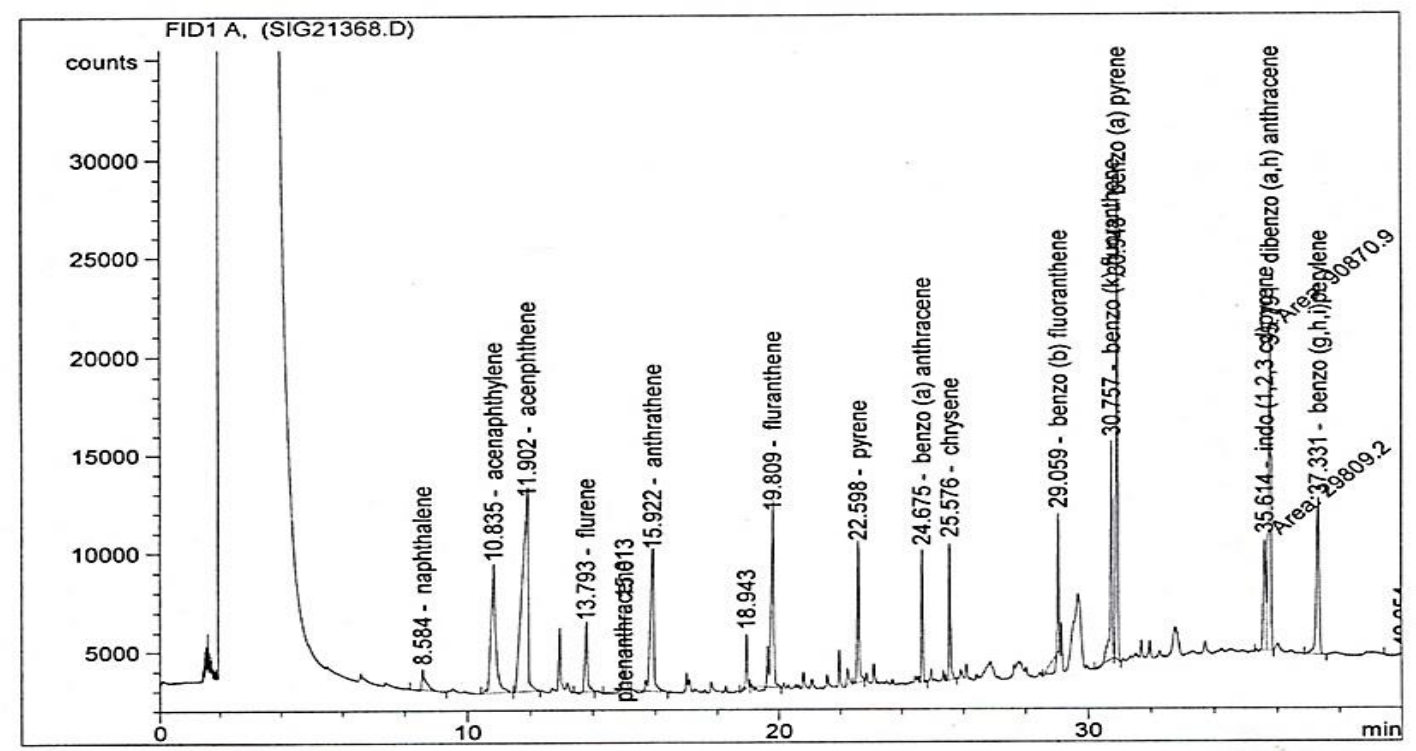

Figure 1: Exemplar for chromatogram of detected PAHs with their retention time.

\section{Results and Discussion}

The current study examined the presence of 16 PAHs compounds; namely; naphthalene, acenaphthylene, acenaphthene, fluorene, phenanthrene, anthracene, fluoranthene, pyrene, benzo [a] anthracene, chrysene, benzo [b] fluoranthrene, benzo [k] fluoranthene, benzo [a] pyrene, Indeno [1,2,3c-d] pyrene, Dibenzo [a,h] anthracene and Benzo [g,h,i] perylene in raw, pan-fried, charcoal-grilled and foil-grilled beef and mutton samples.

\section{PAHs in beef}

From Table (1), it is clear that the percentages of phenanthrene and anthracene in the examined samples were $10 \%$ and $10 \%$ in raw samples, $30 \%$ and $10 \%$ in pan-fried samples, $50 \%$ and $10 \%$ in charcoal-grilled samples, $10 \%$ and $10 \%$ in foil-grilled samples, respectively. Regarding to their residual concentrations, they were detected with mean values of $0.144 \pm 0.144$ and $0.103 \pm 0.103 \mu \mathrm{g} / \mathrm{kg}$ in raw samples, $0.787 \pm 0.420$ and $0.248 \pm 0.248$ $\mu \mathrm{g} / \mathrm{kg}$ in pan-fried samples, $1.501 \pm 0.508$ and $0.61 \pm 0.61 \mu \mathrm{g} / \mathrm{kg}$ in charcoal-grilled samples and $0.571 \pm 0.572$ and $0.174 \pm 0.174 \mu \mathrm{g} / \mathrm{kg}$ in foil-grilled samples, respectively.

Nearly similar results were obtained by Martorell et al. [10] who recorded the mean values of 0.16 and $0.16 \mu \mathrm{g} / \mathrm{kg}$ for both phenanthrene and anthracene in veal respectively. Unlikely, Mishref [11] did not detect phenanthrene in kebab samples but anthracene was recorded with a mean value of $18.2 \pm 25.04 \mu \mathrm{g} / \mathrm{kg}$ which is higher than the current results in charcoal grilled samples. Higher results were also obtained by Sinha et al. [12] and Falcó et al [13] who detected phenanthrene with mean values of 5.3 and $16.7 \mu \mathrm{g} / \mathrm{kg}$, respectively.

Fluoranthene, pyrene, benzo [a] anthracene and benzo [b] fluoranthene compounds were detected only in charcoal grilled samples with the percentages of $10 \%, 10 \%, 30 \%$ and $10 \%$ with mean values of $0.451 \pm 0.451$, $0.543 \pm 0.543,0.545 \pm 0.280$ and $0.189 \pm 0.189$ $\mu \mathrm{g} / \mathrm{kg}$, respectively.

Higher results were obtained by Mishref [11] who detected fluoranthene and benzo [a] anthracene with mean values of 57 and 16.8 $\mu \mathrm{g} / \mathrm{kg}$, respectively, in kebab samples. Moreover, Hassan [14] detected fluoranthene and pyrene in charcoal grilled meat with mean values of 9.22 and $704.24 \mu \mathrm{g} / \mathrm{kg}$, respectively. Additionally, Akpambagetal [15] recorded mean values of both fluoranthene and pyrene as 9.7 and $9.7 \mu \mathrm{g} / \mathrm{kg}$, respectively, which were higher than the recorded results.

Regarding to benzo [a] pyrene, the most dangerous carcinogenic PAHs compound, it was detected in pan-fried, charcoal-grilled and foil-grilled meat samples with the percentages of $20 \%$, each, with mean values of $0.117 \pm 0.085,0.457 \pm 0.306$ and $0.092 \pm 0.062$ $\mu \mathrm{g} / \mathrm{kg}$, respectively, but was not detected in raw samples. 
Table 1: Percentages of PAHs in beef and mutton meat samples exposed to different heat treatments

\begin{tabular}{|c|c|c|c|c|c|c|c|c|c|}
\hline \multirow[t]{2}{*}{ No. } & \multirow[t]{2}{*}{ PAHs } & \multicolumn{4}{|c|}{ Beef samples\% } & \multicolumn{4}{|c|}{ Mutton samples\% } \\
\hline & & Raw & Frying & grilling & $\begin{array}{l}\text { Foil- } \\
\text { grill }\end{array}$ & Raw & Frying & grilling & $\begin{array}{l}\text { Foil- } \\
\text { grill }\end{array}$ \\
\hline 1 & Naphthalene & $0 \%$ & $0 \%$ & $0 \%$ & $0 \%$ & $0 \%$ & $0 \%$ & $40 \%$ & $20 \%$ \\
\hline 2 & Acenaphthylene & $0 \%$ & $0 \%$ & $0 \%$ & $0 \%$ & $0 \%$ & $10 \%$ & $20 \%$ & $10 \%$ \\
\hline 3 & Acenaphthlene & $0 \%$ & $0 \%$ & $0 \%$ & $0 \%$ & $0 \%$ & $0 \%$ & $0 \%$ & $0 \%$ \\
\hline 4 & Fluorine & $0 \%$ & $0 \%$ & $0 \%$ & $0 \%$ & $0 \%$ & $20 \%$ & $40 \%$ & $20 \%$ \\
\hline 5 & Phenanthrene & $10 \%$ & $30 \%$ & $50 \%$ & $10 \%$ & $0 \%$ & $30 \%$ & $60 \%$ & $30 \%$ \\
\hline 6 & Anthracene & $10 \%$ & $10 \%$ & $10 \%$ & $10 \%$ & $0 \%$ & $0 \%$ & $10 \%$ & $0 \%$ \\
\hline 7 & Fluoranthene & $0 \%$ & $0 \%$ & $10 \%$ & $0 \%$ & $0 \%$ & $0 \%$ & $70 \%$ & $50 \%$ \\
\hline 8 & Pyrene & $0 \%$ & $0 \%$ & $10 \%$ & $0 \%$ & $40 \%$ & $50 \%$ & $100 \%$ & $60 \%$ \\
\hline 9 & Benzo(a)anthracene & $0 \%$ & $0 \%$ & $30 \%$ & $0 \%$ & $0 \%$ & $0 \%$ & $30 \%$ & $0 \%$ \\
\hline 10 & Chrysene & $0 \%$ & $0 \%$ & $0 \%$ & $0 \%$ & $0 \%$ & $10 \%$ & $40 \%$ & $20 \%$ \\
\hline 11 & Benzo(b)fluoranthene & $0 \%$ & $0 \%$ & $10 \%$ & $0 \%$ & $0 \%$ & $0 \%$ & $0 \%$ & $0 \%$ \\
\hline 12 & Benzo(k)fluoranthene & $0 \%$ & $0 \%$ & $60 \%$ & $30 \%$ & $0 \%$ & $0 \%$ & $0 \%$ & $0 \%$ \\
\hline 13 & Benzo(a)pyrene & $0 \%$ & $20 \%$ & $20 \%$ & $20 \%$ & $0 \%$ & $10 \%$ & $20 \%$ & $0 \%$ \\
\hline 14 & Indeno( $1,2,3 \mathrm{c}$-d)pyrene & $0 \%$ & $0 \%$ & $0 \%$ & $0 \%$ & $0 \%$ & $0 \%$ & $10 \%$ & $0 \%$ \\
\hline 15 & Dibenzo(a,h)anthracene & $0 \%$ & $0 \%$ & $0 \%$ & $0 \%$ & $30 \%$ & $50 \%$ & $80 \%$ & $50 \%$ \\
\hline 16 & $\operatorname{Benzo}(\mathrm{g}, \mathrm{h}, \mathrm{i})$ perylene & $0 \%$ & $0 \%$ & $20 \%$ & $10 \%$ & $0 \%$ & $10 \%$ & $10 \%$ & $0 \%$ \\
\hline
\end{tabular}

Higher results were obtained by Terzi et al. [16], Akpambagetal [15] and Mishref [11] who detected benzo [a] pyrene with mean values of $24.2,2.8$ and $9.2 \mu \mathrm{g} / \mathrm{kg}$, respectively, in charcoal-grilled meat. However, lower results were recorded by Chung et al. [17], who found mean concentration of benzo [a] pyrene as $0.15 \mu \mathrm{g} / \mathrm{kg}$.

The current findings concerning benzo [a] pyrene didn't exceed the MPL recommended by FAO/WHO (10 part per billion 'ppb'). Concerning benzo [k] fluoranthene and benzo [g,h,i] perylene, they could be detected in charcoal and foil grilled samples only, with the percentages of $60 \%$ and $20 \%$ in charcoalgrilled samples and $30 \%$ and $10 \%$ in foilgrilled samples, respectively. The mean values of benzo [k] fluoranthene in these samples were $1.933 \pm 0.548$ and $0.172 \pm 0.089 \mu \mathrm{g} / \mathrm{kg}$, while they were $0.604 \pm 0.442$ and $0.256 \pm 0.256$ $\mu \mathrm{g} / \mathrm{kg}$ for Benzo [g,h,i] perylene. Lower results were obtained by Martorell et al. [10], who detected benzo [k] fluoranthene and benzo [g,h,i] perylene with mean values of 0.06 and $0.07 \mathrm{ppb}$ respectively, also, Olatunde et al. [18] detected benzo [k] fluoranthene and benzo [g,h,i] perylene with mean values of 0.1 and $0.3 \mathrm{ppb}$, respectively. Both of Mishref [11] and Hassan [14] did not detect any of these two compounds in such samples.
In the current study, it is clear that none of naphthalene, acenaphthylene, acenaphthene, fluorene, chrysene, indeno [1,2,3c-d] pyrene and dibenzo $[\mathrm{a}, \mathrm{h}]$ anthracene were detected in raw, pan-fried, charcoal-grilled and foil-grilled meat samples.

The total PAHs in raw, pan-fried, charcoalgrilled and foil-grilled meat samples were $0.247, \quad 1.152, \quad 6.833$ and $1.265 \mu \mathrm{g} / \mathrm{kg}$ respectively (Table 2). Nearly similar results were obtained by Janoszka et al. [19] who recorded $2.77 \mu \mathrm{g} / \mathrm{kg}$ total PAHs in pan-fried beef collar, while higher results were obtained by Sinha et al. [12] who recorded total PAHs in pan-fried meat as $10.7 \mu \mathrm{g} / \mathrm{kg}$.

Chung et al. [17], who reported that the total PAHs of $0.80 \mathrm{ppb}$ in charcoal-grilled samples which was lower than that obtained in the current study. Higher results were obtained by Falcó et al. [13], Farhadian et al. [5], Jahurul et al. [20], Mishref [11] and Hassan [14], who reported that total PAHs as 13.4, 132, 66.28, 119.8 and $1170.94 \mu \mathrm{g} / \mathrm{kg}$, respectively.

The differences between the obtained results in this study and the others may be attributed to the fat percentage in the meat used in this study, type of charcoal, thickness of meat and well-doneness of meat. 
Table 2: Residual concentrations of PAHs in the examined raw and heat-treated beef samples $(\mathrm{n}=10)$

\begin{tabular}{|c|c|c|c|c|c|c|c|c|c|c|c|c|}
\hline \multirow[b]{2}{*}{ PAHs } & \multicolumn{3}{|c|}{ Raw } & \multicolumn{3}{|c|}{ Fried } & \multicolumn{3}{|c|}{ Charcoal-grilled } & \multicolumn{3}{|c|}{ Foil-grilled } \\
\hline & Min & $\max$ & $\begin{aligned} & \text { Mean } \\
& \pm \text { SE } \\
&\end{aligned}$ & $\min$ & $\operatorname{Max}$ & $\begin{array}{c}\text { Mean } \\
\pm \text { SE }\end{array}$ & $\min$ & $\max$ & $\begin{array}{c}\text { Mean } \\
\pm \text { SE }\end{array}$ & $\min$ & $\max$ & $\begin{array}{c}\text { Mean } \\
\text { SE }\end{array}$ \\
\hline Naphthalene & ND & ND & ND & ND & ND & ND & ND & ND & ND & ND & ND & ND \\
\hline Acenaphthylene & ND & ND & ND & ND & ND & ND & ND & ND & ND & ND & ND & ND \\
\hline Acenapthene & ND & ND & ND & ND & ND & ND & ND & ND & ND & ND & ND & ND \\
\hline Fluorine & ND & ND & ND & ND & ND & ND & ND & ND & ND & ND & ND & ND \\
\hline Phenanthrene & 0 & 1.44 & $0.144 \pm 0.144$ & 0 & 3.47 & $0.787 \pm 0.420$ & 0 & 3.33 & $1.501 \pm 0.508$ & 0 & 5.71 & $0.571 \pm 0.572$ \\
\hline Anthracene & 0 & 1.03 & $0.103 \pm 0.103$ & 0 & 2.48 & $0.248 \pm 0.248$ & 0 & 6.1 & $0.61 \pm 0.61$ & 0 & 1.74 & $0.174 \pm 0.174$ \\
\hline Fluoranthene & ND & ND & ND & ND & ND & ND & 0 & 4.51 & $0.451 \pm 0.451$ & ND & ND & ND \\
\hline Pyrene & ND & ND & ND & ND & ND & ND & 0 & 5.43 & $0.543 \pm 0.543$ & ND & ND & ND \\
\hline Benzo(a)anthracene & ND & ND & ND & ND & ND & ND & 0 & 2.06 & $0.545 \pm 0.280$ & ND & ND & ND \\
\hline Chrysene & ND & ND & ND & ND & ND & ND & ND & $\mathrm{ND}$ & ND & ND & ND & ND \\
\hline Benzo(b)fluoranthene & ND & ND & ND & ND & ND & ND & 0 & 1.89 & $0.189 \pm 0.189$ & ND & ND & ND \\
\hline Benzo(k)fluoranthene & ND & ND & ND & ND & ND & ND & 0 & 4 & $1.933 \pm 0.548$ & 0 & 0.66 & $0.172 \pm 0.089$ \\
\hline Benzo(a)pyrene & ND & ND & ND & 0 & 0.81 & $0.117 \pm 0.085$ & 0 & 2.48 & $0.457 \pm 0.306$ & 0 & 0.52 & $0.092 \pm 0.062$ \\
\hline Indeno(1,2,3c-d)pyrene & ND & ND & ND & ND & ND & ND & ND & ND & ND & ND & ND & ND \\
\hline Dibenzo(o,h)anthracene & ND & ND & ND & ND & ND & ND & ND & ND & ND & ND & ND & ND \\
\hline Benzo(g,h,i)perylene & ND & ND & ND & ND & ND & ND & 0 & 4.24 & $0.604 \pm 0.442$ & 0 & 2.56 & $0.256 \pm 0.256$ \\
\hline Total PAHs & & & 0.247 & & & 1.152 & & & 6.833 & & & 1.265 \\
\hline
\end{tabular}


Table 3: Residual concentrations of PAHs in examined raw and heat-treated mutton samples (n=10)

\begin{tabular}{|c|c|c|c|c|c|c|c|c|c|c|c|c|}
\hline \multirow[b]{2}{*}{ PAHs } & \multicolumn{3}{|c|}{ Raw } & \multicolumn{3}{|c|}{ Fried } & \multicolumn{3}{|c|}{ Charcoal-grilled } & \multicolumn{3}{|c|}{ Foil grilled } \\
\hline & Min & $\max$ & $\begin{aligned} & \text { Mean } \\
& \pm \text { SE } \\
&\end{aligned}$ & Min & $\max$ & $\begin{array}{c}\text { Mean } \\
\pm \text { SE }\end{array}$ & $\min$ & $\max$ & $\begin{array}{c}\text { Mean } \\
\pm \text { SE }\end{array}$ & Min & $\max$ & $\begin{array}{c}\text { Mean } \\
\text { SE }\end{array}$ \\
\hline Naphthalene & ND & ND & ND & ND & ND & ND & 0 & 6.62 & $1.783 \pm 0.823$ & 0 & 3.58 & $0.69 \pm 0.458$ \\
\hline Acenaphthylene & ND & ND & ND & 0 & 0.53 & $0.053 \pm 0.053$ & 0 & 3.3 & $0.596 \pm 0.400$ & 0 & 0.71 & $0.071 \pm 0.071$ \\
\hline Acenapthene & ND & ND & ND & ND & ND & ND & ND & ND & ND & ND & ND & ND \\
\hline Fluorine & ND & ND & ND & 0 & 1.27 & $0.23 \pm 0.154$ & 0 & 8.75 & $1.848 \pm 0.952$ & 0 & 3.31 & $0.526 \pm 0.365$ \\
\hline Phenanthrene & ND & ND & ND & 0 & 1.44 & $0.289 \pm 0.160$ & 0 & 1.46 & $0.662 \pm 0.189$ & 0 & 0.81 & $0.200 \pm 0.105$ \\
\hline Anthracene & ND & ND & ND & ND & ND & ND & 0 & 0.49 & $0.049 \pm 0.049$ & $\mathrm{ND}$ & ND & ND \\
\hline Fluoranthene & ND & ND & ND & ND & ND & ND & 0 & 1.52 & $0.654 \pm 0.182$ & 0 & 1.81 & $0.459 \pm 0.191$ \\
\hline Pyrene & 0 & 3.67 & $0.917 \pm 0.417$ & 0 & 8.3 & $3.177 \pm 1.121$ & 1.02 & 23.42 & $13.979 \pm 1.884$ & 0 & 6.91 & $3.426 \pm 0.968$ \\
\hline Benzo(a)anthracene & ND & ND & ND & ND & ND & ND & 0 & 16.57 & $2.517 \pm 1.744$ & $\mathrm{ND}$ & ND & ND \\
\hline Chrysene & ND & ND & ND & 0 & 4.38 & $0.438 \pm 0.438$ & 0 & 14.6 & $3.491 \pm 1.729$ & 0 & 3 & $0.565 \pm 0.378$ \\
\hline Benzo(b)fluoranthene & ND & ND & ND & ND & ND & ND & ND & ND & ND & ND & ND & ND \\
\hline Benzo(k)fluoranthene & ND & ND & ND & ND & ND & ND & ND & ND & ND & ND & ND & ND \\
\hline Benzo(a)pyrene & ND & ND & ND & 0 & 0.19 & $0.019 \pm 0.019$ & 0 & 0.19 & $0.030 \pm 0.021$ & ND & ND & ND \\
\hline Indeno( $1,2,3 \mathrm{c}$-d $)$ pyrene & ND & ND & ND & ND & ND & ND & 0 & 5.33 & $0.533 \pm 0.533$ & $\mathrm{ND}$ & ND & ND \\
\hline Dibenzo(a,h)anthracene & 0 & 0.9 & $0.173 \pm 0.098$ & 0 & 1.05 & $0.4 \pm 0.148$ & 0 & 0.98 & $0.503 \pm 0.099$ & 0 & 0.71 & $0.246 \pm 0.863$ \\
\hline $\operatorname{Benzo}(\mathrm{g}, \mathrm{h}, \mathrm{i})$ perylene & ND & ND & ND & ND & ND & ND & 0 & 1.74 & $0.174 \pm 0.174$ & 0 & 0.96 & $0.096 \pm 0.096$ \\
\hline Total PAHs & & & 1.09 & & & 4.606 & & & 26.819 & & & 6.279 \\
\hline
\end{tabular}




\section{PAHs in mutton}

The results in Table (3) indicated that the percentages of pyrene and dibenzo [a,h] anthracene in the examined samples were $40 \%$ and $30 \%$ in raw samples, $50 \%$ and $50 \%$ in pan-fried samples, $100 \%$ and $80 \%$ in charcoal-grilled samples and $60 \%$ and $50 \%$ in foil-grilled samples, respectively. Regarding to their residual concentrations, they were detected with mean values of $0.19 \pm 0.417$ and $0.173 \pm 0.098 \mu \mathrm{g} / \mathrm{kg}$ in raw samples, $3.177 \pm 1.121$ and $0.4 \pm 0.148 \mu \mathrm{g} / \mathrm{kg}$ in pan-fried samples, $13.979 \pm 1.884$ and $0.503 \pm 0.099 \mu \mathrm{g} / \mathrm{kg}$ in charcoal-grilled samples and 3.426 \pm 0.968 and $0.246 \pm 0.863 \mu \mathrm{g} / \mathrm{kg}$ in foil-grilled samples, respectively.

The percentages of acenaphthylene, flourene, phenanthrene and chrysene in the current study were $10 \%, 20 \%, 30 \%$ and $10 \%$ in pan-fried samples, $20 \%, 40 \%, 60 \%$ and $40 \%$ in charcoal-grilled samples and $10 \%$, $20 \%, 30 \%$ and $20 \%$ in foil-grilled samples, respectively. Their mean residual concentrations were $0.053 \pm 0.053,0.23 \pm 0.154$, $0.289 \pm 0.159$ and $0.438 \pm 0.438 \mu \mathrm{g} / \mathrm{kg}$ in panfried samples, $\quad 0.596 \pm 0.4, \quad 1.848 \pm 0.952$, $0.662 \pm 0.189$ and $3.491 \pm 1.729 \mu \mathrm{g} / \mathrm{kg}$ in charcoal-grilled samples and $0.071 \pm 0.071$, $0.526 \pm 0.365, \quad 0.2 \pm 0.105$ and $0.565 \pm 0.378$ $\mu \mathrm{g} / \mathrm{kg}$ in foil-grilled samples, respectively.

Concerning benzo [a] pyrene, it was detected in fried and charcoal-grilled samples with mean values of $0.019 \pm 0.019$ and $0.030 \pm 0.021 \mu \mathrm{g} / \mathrm{kg}$, respectively. Higher results were obtained by Ayguns and Kabadayi, [21] and Kao et al. [22], who recorded benzo [a] pyrene levels as $43.8 \pm 1.8$ and $5.8 \pm 0.5 \mu \mathrm{g} / \mathrm{kg}$ in grilled lamb meat and lamb steak, respectively.

Naphthalene, fluoranthene and benzo [g,h,i] perylene compounds were detected in charcoal and foil-grilled samples only, with the percentages of $40 \%, 70 \%$ and $10 \%$ in charcoal-grilled samples and 20\%, 50\% and $10 \%$ in foil-grilled samples, respectively. Their mean values were $1.783 \pm 0.823$ and $0.69 \pm 0.458 \mu \mathrm{g} / \mathrm{kg}$ for naphthalene, $0.654 \pm 0.182$ and $0.459 \pm 0.191 \mu \mathrm{g} / \mathrm{kg}$ for fluoranthene, $0.174 \pm 0.174$ and $0.096 \pm 0.096$ for benzo [g,h,i] perylene.
Anthracene, benzo [a] anthracene and indeno $[1,2,3 \mathrm{c}-\mathrm{d}$ pyrene compounds were detected only in charcoal-grilled samples in our study with the percentages of $10 \%, 30 \%$ and $10 \%$, respectively. Their mean values were $\quad 0.049 \pm 0.049, \quad 2.517 \pm 1.744$ and $0.533 \pm 0.533 \mu \mathrm{g} / \mathrm{kg}$, respectively. In the current study, it is clear that non of acenaphthene, benzo [b] fluoranthene and benzo [k] fluoranthene could be detected in raw, fried, charcoal-grilled and foil-grilled mutton samples. It is clear from Table (3) that the total PAHs for raw, pan-fried, charcoal-grilled and foil-grilled mutton samples were 1.09, 4.606, 26.819 and $6.279 \mu \mathrm{g} / \mathrm{kg}$, respectively.

For both beef and mutton

It is obvious that quantitative PAHs profile was different in pan-fried, charcoal-grilled and foil-grilled meat samples, which may be attributed to cooking temperature, cooking method and cooking time [5]. Generally, the formation mechanism of PAHs in grilled or smoked diets is unknown, it is generally considered that at least 3 possible mechanisms exist: The 1st mechanism is the organic matter pyrolysis as fat, carbohydrates and protein at temperatures higher than $200 \mathrm{oC}$, and the formation of $\mathrm{PAH}$ mainly arise at a temperature ranges from 500 to $900 \mathrm{oC}$ [23]. The largest levels of PAHs may be arising from fat pyrolysis [24].

The second mechanism is due to the direct contact of the dripping arise from lipids at an extreme heat directly over a flame. This situation could produce volatile PAHs which then sticked to the food surface and the smokes rise [25]. The third mechanism is the incomplete combustion of charcoal which can generate PAHs that are brought onto the surface of the food [26].

It is obvious that the total PAHs increased after thermal treatments and this result came in harmony with WHO [4], which reported that high levels of PAHs are not usually observed in raw food. In addition, Phillips [27] mentioned that cooking processes can generate PAHs in food. It was observed that total PAHs of both beef and mutton samples is lower in fried samples than that of charcoal and foil grilled samples. On the contrary, Perelló [28] stated that the highest PAHs concentrations found after frying. 
Meanwhile, Larson et al. [29] mentioned that frying didn't lead to any appreciable increase of the original trace level, and this was in agreement with this study.

Interestingly, it was found that total PAHs decreased in foil-grilled samples than charcoal-grilled one, this mean that when meat is wrapped with aluminum foil during grilling, it leads to a decrease in the total PAHs in the meat samples. These results are in agreement with Farhadian et al [30], who used aluminum foil and banana leaves to reduce total PAHs in meat samples during grilling and reported that this method is working well.

The health risk associated to the high concentration of benzo(a)pyrene, benzo(a)anthracene and chrysene in the present study was reported by Nisbet and LaGoy [31] and IARC [32], who recorded that the PAHs were proven to be animal carcinogens and in human they are suspected to be carcinogen. Therefore, many considerations should be taken before consumption of meat grilled over charcoal because large amounts of PAHs could be eaten in a single diet.

The total PAHs in beef is lower than that of mutton. This may be due to the mutton used in this study was higher in fat than beef. The percentage of fat plays an important role in PAHs formation, because barbecuing leads to melting of fat that dropped during the grilling period which provides the formation of PAHs [33].

\section{Conclusion}

In conclusion, the total PAHs increased after thermal treatments than that in raw samples. Additionally, in both beef and mutton samples, total PAHs is lower in fried samples than that of charcoal and foil-grilled samples. Total PAHs decreased in foil-grilled samples than charcoal grilled one, this means that, when meat wrapped in aluminum foil during grilling, it leads to a decrease in the total PAHs in the meat samples. Benzo [a] pyrene didn't exceed the MPL recommended by FAO/WHO (10 ppb). So, it seems that it is preferable to the consumers to wrap the charcoal grilled meat in an aluminum foil prior to grilling.

\section{Conflict of interest}

None of the authors have any conflict of interest to declare.

\section{References}

[1] Jägerstad, M. and Skog, K. (2005): Review genotoxicity of heat-processed foods. Mutat Res, 574(1-2): 156-172.

[2] EFSA (European Food Safety Authority) (2008): Scientific opinion of the panel on contaminants in the food chain on a request from the European Commission on polycyclic aromatic hydrocarbons in food. EFSA J, 724:1-114.

[3] Llobet, J. M.; Falcó, G.; Bocio, A. and Domingo, J. L. (2006): Exposure to polycyclic aromatic hydrocarbons of edible marine species in Catalonia, Spain. J Food Protect, 69(10): 2493-2499.

[4] World Health Organization (WHO) (1998): Selected non-heterocyclic polycyclic aromatic hydrocarbons. Environ. Health Crit. No. 202. Geneva, Switzerland.

[5] Farhadian, A.; Jinap, S.; Abas, F. and Sakar, Z.I. (2010): Determination of polycyclic aromatic hydrocarbons in grilled meat. Food Control, 21(5): 606-610.

[6] International Agency for Research on Cancer (IARC) (1987): Overall evaluation of carcinogenicity: An updating of IARC Monographs, vol. 1-42, IARC Monographs on the Evaluation of Carcinogenic Risks to Humans, Suppl. 7, IARC, Lyon.

[7] European Commission (2006): Commission regulation (EC) no. 1881/2006 of 19 December 2006 setting maximum levels for certain contaminants in foodstuffs. Official Journal of the European Union, 364/5.

[8] Villeneuve, J. P.; Carvalho, F. P.; Fowler, S. W. and Cattini, C. (1999): Levels and trends of PCBs, chlorinated pesticides and petroleum hydrocarbons in mussels from the NW Mediterranean coast: comparison of concentrations in 19731974 and 1988 1989. Sci Total Environ, 237: 57-65. 
[9] Moret, S. and Conte, LS. (2000): Polycyclic aromatic hydrocarbons in edible fats and oils: occurrence and analytical methods. J Chromatogr A, 882(1):245-253.

[10] Martorell, I.; Perelló, G.; Martí-Cid, R.; Castell, V.; Llobet, J. M. and Domingo, J. L. (2010): Polycyclic aromatic hydrocarbons (PAH) in foods and estimated PAH intake by the population of Catalonia, Spain, temporal trend. Environ Int, 36(5):424-432.

[11] Mishref, M. A. (2014): Assessment of some polycyclic aromatic hydrocarbons residues in prefabricated meat for consumption and it's relevance to food safety. M. V. Sc. Thesis, Fac. Vet. Med., Zagazig Univ., Egypt.

[12] Sinha, R.; Rothman, N.; Brown, E.; Mark, S.; Hoover, R.; Caporaso, N.; Levander, O.; Knize, M.; Lang, N. and Kadlubar, F. (1994): Pan-Fried Meat Containing High Levels of Heterocyclic Aromatic Amines but Low Levels of Polycyclic Aromatic Hydrocarbons Induces Cytochrome P4501A2 Activity in Humans. Cancer Res, 54(23): 6154-6159.

[13] Falco, G.; Domingo, J. L.; Llobet, J. M.; Teixido, A.; Casas, C. and Müller, L. (2003): Polycyclic Aromatic Hydrocarbons in Foods: Human Exposure through the Diet in Catalonia, Spain. J Food Protect, 66(12): 23252331.

[14] Hassan, S. M. (2016): Detection of Some Chemical Residues In Grilled Meats With Special Reference To Their Public Health Importance. M. V. Sc. Thesis, Fac. Vet. Med., Zagazig Univ., Egypt.

[15] Akpambanga, V.O.E.; Purcarob, G.; Lajidea, L.; Amooa, I.A.; Conteb, L.S. and Moret, S. (2009): Determination of polycyclic aromatic hydrocarbons (PAHs) in commonly consumed Nigerian smoked/grilled fish and meat. Food Addit Contam, 26(7): 1096-1103.

[16] Terzi, G.; Çelik. T.H. and Nisbet, C. (2008): Determination of benzo[a]pyrene in Turkish döner kebab samples cooked with charcoal or gas fire. Irish J Agri Food Res, 47: 187-193.
[17] Chung, S.Y.; Ramesh, R. Y.; Kim, J.S.; Kwon, K.; Kim, M.C. and David, B. (2011): Effects of grilling and roasting on the levels of polycyclic aromatic hydrocarbons in beef and pork. Food Chem, 129(4): 1420-1426.

[18] Olatunde, O.S.; Fatoki, O.S.; Opeolu, B.O. And Ximba, B.J. (2014): Determination of polycyclic aromatic hydrocarbons [PAHs] in processed meat products using gas chromatography Flame ionization detector. Food Chem, 156: 296-300.

[19] Janoszka, B.; Warzecha, L.; Błaszczyk, U. and Bodzek, D. (2004): Organic compounds formed in thermally treated high-protein food, Part I: Polycyclic aromatic hydrocarbons. Acta Chromatogr, 14: 115-128.

[20] Jahurul, M.H.A.; Jinap, S.; Zaidul I.S. M.; Sahena, F.; Farhadian, A. and Hajeb, P.(2013):Determination of fluoranthenebenzo [b] fluoranthene and benzo [a] pyrene in meat and fish products and their intake by Malaysian. Food biosciences, 1:73-80.

[21] Aygün, S. and Kabadayi, F. (2005): Determination of benzo [a] pyrene in charcoal grilled meat samples by HPLC with fluorescence detection. Int $\mathrm{j}$ food Sci Nutr, 56(8): 581-585.

[22] Kao, T.H.; Chen, S.; Huang, C.W.; Chen, C.J. and Chen, B.H. (2014): Occurrence and exposure to polycyclic aromatic hydrocarbons in kindling-free-charcoal grilled meat products in Taiwan. Food Chem Toxicol, 71: 149-158.

[23] Knize, M. G.; Salmon, C. P.; Pais, P. and Felton, J. S. (1999): Food heating and the formation of heterocyclic aromatic amine and PAH mutagens/carcinogens. In L. S. Jackson, M. G. Knize, \& J. N. Morgan (Eds.), Impact of processing on food safety (pp. 179-193). New York: Kluwer Academic.

[24] Bartle, K.D. (1991): Analysis and occurrence of PAHs in food. In C. S. Creaser, \& R. Purchase (Eds.), Food contam: Sources and surveillance (pp. 
41-60). Cambridge: Royal Society of Chemistry.

[25] European Commission Scientific Committee on Foods (2002): Opinion of the scientific committee on food on the risks to human health of polycyclic aromatic hydrocarbons in food expressed on fourth December 2002. Brussels, Eur. Comm. health and consumer Protection.

[26] Dyremark, A.; Westerholm, R.; Övervik, E. and Gustavsson, J. (1995): PAH emissions from charcoal grilling. Atmos Environ, 13: 1553-1558.

[27] Phillips, D. H. (1999): Polycyclic aromatic hydrocarbons in the diet. Mutat Res, 443:139-147.

[28] Perelló, G.; Martí-Cid, R.; Castell, V.; Llobet, J.M. and Domingo, J.L. (2009): Concentrations of polybrominated diphenyl ethers, hexachlorobenzene and polycyclic aromatic hydrocarbons in various foodstuffs before and after cooking. Food Chem Toxicol, 47(4): 709715.

[29] Larsson, B.K.; Sahlberg, G.P.; Eriksson, A.T. and Busk, L.A. (1983): Polycyclic aromatic hydrocarbons in grilled food. $\mathbf{J}$ Agr Food Chem, 31(4): 867-873.

[30] Farhadian, A.; Jinap, S.; Hanifah, H.N. and Zaidul, I.S. (2011): Effects of meat preheating and wrapping on the levels of polycyclic aromatic hydrocarbons in charcoal-grilled meat. Food Chem, 124(1): 141-146.

[31] Nisbet, I.C.T. and LaGoy, P.K. (1992): Toxic equivalency factor (TEFs) for polycyclic aromatic hydrocarbons (PAHs). Regul Toxicol Pharm, 16(3): 290-300.

[32] International Agency Research for Cancer (IARC) (2010): Monographs on the evaluation of carcinogenic risk to humans. Some non-heterocyclic polycyclic aromatic hydrocarbons and some related exposures, Vol. 92. Lyon, France: IARC, 36-37.

[33] Viegas, O.; Novo, P.; Pinto, E.; Pinho, O. and Ferreira, O. (2012): Effect of charcoal types and grilling conditions on formation of heterocyclic aromatic amines (HAs) and polycyclic aromatic hydrocarbons (PAHs) in grilled muscle foods. Food Chem Toxicol, 50(6): 2128-2134.

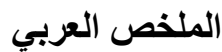

تأثير طرق الطهي المختلفة علي تكوين المواد الهيلروكربونية الأروماتية متعددة الحلقات فى اللحوم

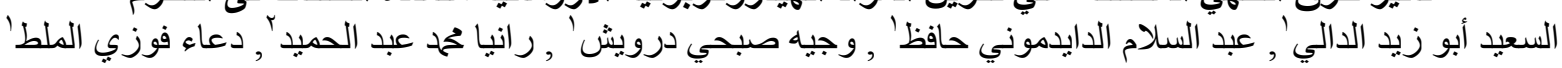

$$
\begin{aligned}
& \text { 'قسم مر اقبة الأغذية, كلية الطب البيطرى, جامعة الزقازيق } \\
& \text { 'قسم متبقيات المبيدات وتلوث البيئة, المعمل المركزي للمبيدات, مركز البحوث الزر اعبة, الدقي, الجيزة }
\end{aligned}
$$

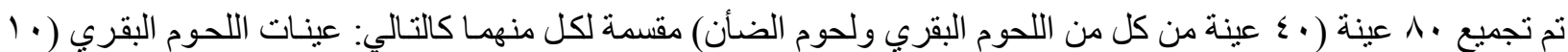

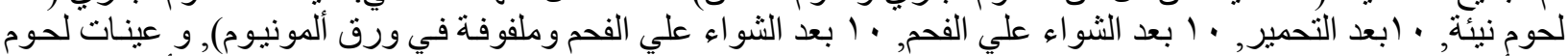

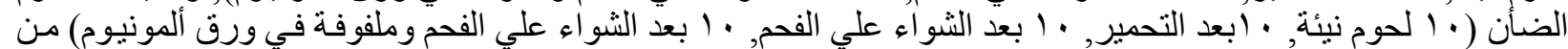

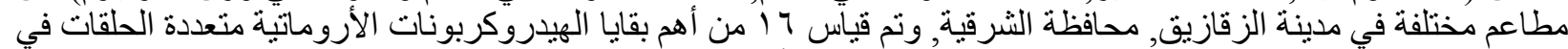

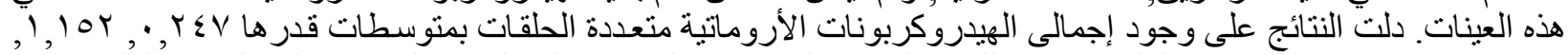

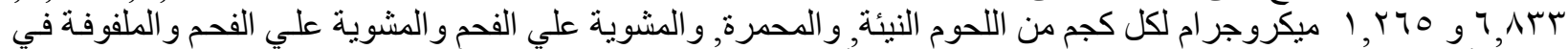

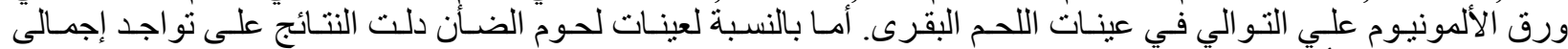

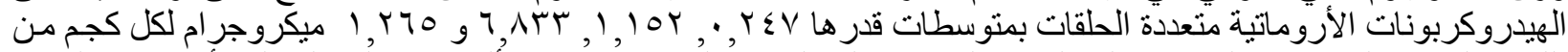

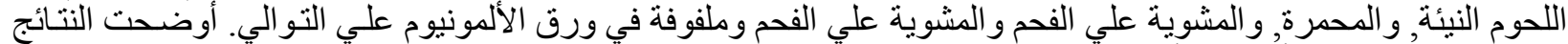
ان لف اللحوم بورق الألمونيوم أدت إلي تقليل هذه المو اد الخطيرة. 